\title{
Incorporating Indigenous and Women's Voices in Canadian Church History ${ }^{1}$
}

\section{Lucille Marr, The Presbyterian College}

Abstract: This article highlights the value - indeed, necessity - of conceptualizing and teaching the histories of women and Indigenous people as an integral part of Canadian church history. This is accomplished by exploring three of the myriad reasons these inclusions are important, namely: (1) because we avoid it; (2) because history is essential in identity-building; (3) because the multi-faceted histories of Indigenous peoples and women are necessary if we are to have fuller understandings of who we are as Canadian people. In concluding, it is suggested that the act of incorporating Indigenous and women's voices into Canadian church history honours the relational nature of knowing - their history is our history, and we cannot know the latter without the former.

Key Words: Canadian church history; Indigenous history; women's history; identity-building.

$\mathrm{H}$ istorian Urban Holmes once suggested that the early Christians expected the Parousia; what they got was the church. It is sobering to think about what those early Christian martyrs, many of whom have lain for nearly two millennia in their final earthly resting place, might think of the way the church has unfolded. And yet, although the history of the church is fraught with failure, it is still the best reflection of the hope of the resurrection. ${ }^{2}$ In the class on Canadian Church History that I taught for some years, I began each term by requiring students to read an article written by the Presbyterian historian John S. Moir. "In Search of a Christian Canada" is based on a three-part lecture series that Professor Moir addressed to McGill University's Faculty of Religious Studies twenty-five years ago. He argued that addressing Canada's Christian origins and context is necessary as we attempt to come to an understanding of who we are as a nation. ${ }^{3}$ Moir was concerned with the influence of Christianity on the development of the Canadian nation, but he was uneasy with what he termed "the balkanization" of Canada's history, separating it out in its various parts as social historians are wont to do.

In my view, if we are going to move forward in a healthy way, it is necessary to consider the history of the many Canadians who have been affected by a variety of manifestations of intolerance ${ }^{4}$ : Indigenous Peoples, Chinese Canadians, Japanese Canadians, Canadians with roots in Eastern Europe, Africa, and

1. A version of this paper was presented as the Presidential Address for the Canadian Society of Church History at Ryerson University, on June 2, 2017, and was printed in the society's publication Historical Papers as "Reflections on the Necessity of Canadian Church History" (2017). This version was created for the colloquium, "500 years of Reformation \& The World's Religions," organized by the Centre for Research on Religion (CREOR), McGill University, and presented on October 30, 2017.

2. Urban T. Holmes III, A History of Christian Spirituality: An Analytical Introduction (New York: Seabury Press, 1981); see also N.T. Wright, Surprised by Hope: Rethinking Heaven, the Resurrection, and the Mission of the Church (New York: Harper Collins Publishers, 2008).

3. J.S. Moir, "The Search for a Christian Canada," in Christianity in Canada: Historical Essays, ed. Paul Laverdure (Yorktown, SK: Redeemer's Voice Press, 2002), 9-24.

4. For a helpful discussion, please see Allan Levine, "Slow Road to Tolerance," Canada's History (April-May 2016): 4147. 
South America, to say nothing of women of every cultural origin who still make up more than half the population. On some of our Canadian currency - a commemorative $\$ 10.00$ bill - four faces appear. Canada's first Prime Minister, John A. MacDonald, has been joined by his Quebec counterpart Georges- Etienne Cartier, both founding fathers of Confederation. They do not appear alone. The commemorative ten-dollar bill also features two more individuals: James Gladstone, the first Indigenous senator, and Agnes Macphail, Canada's first female Member of Parliament. ${ }^{5}$

I want to look more closely at the two groups symbolized by Gladstone and MacPhail: Indigenous Peoples and women. I have devoted much of my career to researching and writing on both women and Indigenous Peoples, and I have worked at integrating both into my teaching. ${ }^{6}$ We are acknowledging our complicity in colonialism, and coming closer to recognizing women's contributions to Canadian society and the churches; commemoration is another important step, to celebrate alongside the blanks, and the ugliness of the past. Over four decades of scholarly work have shown me that without the contributions of women and Indigenous Peoples, we would have no history. Those histories are our histories as much as the leaders who have shaped the churches and our country.

Following are several suggestions about why the history of Indigenous Peoples and women is necessary; about why it is essential to incorporate these histories into our writing and teaching. ${ }^{7}$ Why is this history necessary? There are many reasons why the history of Indigenous Peoples and women is necessary, but for purposes of this talk, I will suggest three: (1) because we avoid it; (2) because history is essential in identity-building; (3) because the multi-faceted histories of Indigenous Peoples and women are necessary if we are to have fuller understandings of who we are as a Canadian people.

\section{Because We Avoid It}

As Canadians we are known to avoid discussing controversial topics. Possibly none more than religion. You may remember Clifford Kraus's article published in 2003 in the New York Times, "In God We Trust...Canadians Aren't So Sure." When Yann Martel changed the way he wrote his Life of Pi to accommodate the Canadian preference to be quiet about religion, it made news. Kraus cited two Canadian church historians - Marguerite Van Die and David Marshall - in an attempt to explain the Canadian reluctance to speak about religion. ${ }^{8}$ As Canadians, we do not like controversy. Our tolerance means that we avoid potentially divisive aspects of our history. We refuse to talk about them - but at what cost? Three

5. Bank of Canada, “Celebrating Canada's 150th,” http://www.bankofcanada.ca/banknotes/banknote150/.

6. See, for instance, the following: Lucille Marr, "Women and Christianity," in Women and the Future of Religion, ed. Arvind Sharma, (New York: Suny Press, forthcoming); Marr, "Conflict, Confession and Conversion: H. Frances Davidson's Call to Brethren in Christ Mission," Brethren in Christ History \& Life 40, no. 3 (December 2017): 335-52; Marr, "Jane Drummond Redpath," in Still Voices, Still Heard, ed. J.S.S. Armour et al. (Eugene, OR: Wipf \& Stock, 2015), 44-62; Marr, “"Paying the Price of War': Women on the Home Front," in Canadian Churches and the First World War, ed. Gordon L. Heath (Eugene OR: Pickwick Publications, 2014), 263-283; Marr, "Breaking the Silence on Suicide and Mental Illness: The Brethren in Christ, 1968-1989," Journal of Mennonite Studies 29 (2011): 121-32; Marr "Writing a Woman's Life: Lucille Brechbill Lady, 1910-1968," Brethren in Christ History and Life 33, no. 1 (2010): 3-50; Marr, "Spirituality and a Heart for Justice: Mennonite Central Committee and the Ontario Aboriginal Community," Brethren in Christ History and Life 26, no. 2 (2003): 45-61; Marr, “'Breaking Down Barriers': Mennonite Central Committee Ontario and Ontario Native Communities," Journal of Mennonite Studies 18 (2000): 78-91.

7. Thirty-five years ago, on April 1, 1982, Gerda Lerner spoke to the Organization of American Historians in Philadelphia, on "The Necessity of History and the Professional Historian." It has since been published in her thought-provoking book Why History Matters: Life and Thought (New York: Oxford University Press, 1997): 113-28.

8. Clifford Kraus, “In God We Trust...Canadians Aren't So Sure,” New York Times, March 26, 2003. http://www.nytimes.com /2003/03/26/world/letter-from-the-americas-in-god-we-trust-canadians-aren-t-so-sure.html. 
Three summers ago, as I was heading down my street to do some errands, a student stopped me. She was studying at the Montreal School of Theology, where students are required to take a class entitled "Canadian Church History." She had recently completed the class. She stopped, plunked her bag on the sidewalk, and took out a book. You have to read this, she said, as she thrust it into my hands. The book? Thomas King's The Inconvenient Indian. ${ }^{9}$

I have to admit that she had already promoted King in class, and I really had no intention of adding him to my always lengthy reading list. I saw King as a popular writer, a writer of fiction, someone that appealed to young people; I am a historian, and well, I have been studying and teaching Indigenous history for forty years. The book sat on my shelf for months - well, actually, years. I lent it to my son to read; I bought a copy for my son-in-law for Christmas. But I avoided it. Then, finally, that student was coming up to graduation and I wanted to return her book. I wanted to return it having taken it seriously, so I decided I must bite the bullet, and I read it. "Novelist, short-story writer, essayist, screenwriter, photographer ... Member of the Order of Canada and two-time nominee for the Governor General's Award" - I discovered the truth in what The Canadian Encyclopedia says about Thomas King. Indeed, The Inconvenient Indian confirms King's reputation as "one of the finest contemporary Aboriginal writers in North America."10

Addressing the penchant to avoid Indigenous history, King opines, “... this sloughing off of history is not an idea I came up with on my own. It is an approach to North American Native history that has been around for a while and appears to be gaining in popularity." ${ }^{11}$ King goes on to describe a book that came out in response to the Mohawk land claim in my home community of Caledonia, Ontario: Helpless! Caledonia's Nightmare of Fear and Anarchy and How the Law Failed All of Us. ${ }^{12}$ Globe and Mail journalist Christie Blatchford's inflammatory journalism is something I usually avoided reading, but King's citation from the introduction of her book underscores the point. What we do as church historians is necessary because many Canadians make a point of avoiding it, even outright ignoring it. Listen to Blatchford's insistence that the best way to approach history is to avoid it:

This book is not about Aboriginal land claims. This book is not about the wholesale removal of seven generations of indigenous youngsters from their reserves and families ... or the abuse dished out to many of them at the residential schools [...] This book is not about the dubious means of the reserve system which may better serve those who wish to see native people fail $[\ldots]^{13}$

Instead, Blatchford chose to highlight the negative effects experienced by the occupants of the Douglas Creek Estates, and on non-indigenous Caledonians and how the law failed to protect them. As King so poignantly expresses, "ignoring the past is certainly an expedient strategy." 14 Yes, the history of Indigenous people and land claims is necessary for us as Canadian church historians, because, at best, most Canadians avoid it, at worst, they deny it. As I was writing this talk, I had several confirmations of this mindset that

\footnotetext{
9. Thomas King, The Inconvenient Indian: A Curious Account of Native People in North America (Toronto: Doubleday Canada, 2002).

10. Brian John Busby, “Thomas King,” The Canadian Encyclopedia (Historica Canada). Article published April 7, 2008 ; Last modified April 4, 2014. http://www.thecanadianencyclopedia.ca/en/article/thomas-king/.

11. King, The Inconvenient Indian, 165.

12. Christie Blatchford, Helpless: Caledonia's Nightmare of Fear and Anarchy, and How the Law Failed All of Us (Toronto: Doubleday, 2010).

13. Blatchford, cited in King, Inconvenient Indian, 166.

14. King, Inconvenient Indian, 166. Timothy C. Winegard has confirmed King's point in his review of this book. See Native Studies Review 20, no. 1 (2011), 117-19, http://publications.usask.ca/nativestudiesreview/reviews/20-1Reviews.pdf.
} 
that characterizes us as Canadians. I would like to share one. For theology students in the three colleges associated with The School of Religious Studies, "Canadian Church History" is a compulsory class. Some students ask why? It seems irrelevant, they say. One student told me at the end of this past term that she wondered how we would ever put in a whole semester focusing on Canadian church history. Canada was only celebrating its 150 th anniversary, she said. What could be worthwhile enough to make it compulsory for students to spend an entire semester studying the history of the church in Canada? This student was surprised, and gratified, she told me at the end of the term, to learn that what's shaped us goes back hundreds of years, even millenniums. And she acknowledged that she had gained a great deal - including what she learned about Indigenous history, and women's history. This brings another story to mind.

A few years ago, a young man signed up for "Women and the Christian Tradition," which I also taught at the Presbyterian College for a number of years. He sat in the very back of the classroom all term, a minority in a class sadly still mostly comprised of women. Finally, towards the end of the term he divulged why he was there. He was completing an honours history degree he told the class, and he realized he had managed to avoid learning about women. He knew his education was incomplete and he wanted to remedy that.

There are still students who worry that including Indigenous and women's histories will mean that some of the other important aspects of history will be left out. At the same time, many of today's students are hungering for more - some tell me they want more Indigenous history; others say they want more women's history. Why? Because they are sensing that the many histories of Indigenous Peoples and women are essential to understanding more deeply who we are as human beings; they are sensing that the many histories of Indigenous Peoples and women are essential to identity-building, as we broaden and deepen our understandings of Christianity, and its place in the Canadian past.

\section{History is Essential to Identity Building}

Positive identity and history are closely connected. About the same time as Moir gave his lecture series "In Search of a Christian Canada," an honourary Blackfoot chief Hugh Dempsey addressed the important question of Indigenous identity. Dempsey had been Curator and Director of the Glenbow Museum for twenty-five years. With his background we can be quite certain Dempsey knew what he was talking about when he said ${ }^{15}$ : "Indians have good reason to be proud of themselves and yet this pride is all too often lacking. I feel very strongly," he insisted, "that if the Indians are going to progress as a people, they must have this pride or they must regain it." 16

What do children - Indigenous and otherwise - see in history books? In the media? As Thomas King has helped his readers see, Indigenous children, like non-Indigenous children, grow up with movies of the wild west, where the Indian is always the other, and often the bad guy. Images of Indians sell things, and their names are names of cities, parks, and recreational sites. In the area of southern Ontario between Caledonia and Brantford where I grew up, Aboriginal images are everywhere. They are synonymous with towns - Brantford, Cayuga, Seneca; they are the names of colleges such as Mohawk College; they even

15. Hugh A. Dempsey, The Gentle Persuader: A Biography of James Gladstone Indian Senator (Saskatoon, SK: Western Producer Prairie Books, 1986), vii-viii; Barb Livingston, "Hugh Dempsey: Author and Historian," Calgary Herald, January 2, 2016, http://calgaryherald.com/news/local-news/hugh-dempsey-author-and-historian.

16. Dempsey, "Role of Native Cultures in Western History: An Alberta Focus," in The Cultural Maze: Complex Questions on Native Destiny in Western Canada, ed. John W. Friesen (Calgary, AB: Detselig Enterprises, 1991), 39. 
sell gas - as the Mohawk gas stations across the country distinguished by the Indian headdress marker attest. $^{17}$

As Hugh Dempsey insisted, "lack of pride is one of the most serious problems facing the Indians today." He goes on to cite a survey done among school children on the Côte Reserve in Saskatchewan. Given a list of 10 ethnic and racial groups - English, German, Black, Indian, Chinese, to name some of them, these children were invited to order them in the preference of which they would choose to belong, if such a choice had been theirs. Indians hit rock bottom on the list of most of the Indigenous children of the Saskatchewan's Côte Reserve who participated in the survey. As Dempsey declared: "when you have a group of people who consider themselves so inferior that they place their own race at the bottom of the list of what they would want to be, you can be sure that there is a very serious problem." 18

This is a problem indeed. Women of all cultures face a similar problem. Psychologists tell us that the absence of strong models in history leaves a huge gap in women's sense of identity. In my classes, I like to use Psychologists Linda Tschirhart Sanford and Mary Ellen Donovan to illustrate. And Iquote:

Probably the field in which men have been the most thoroughly showcased and women the most thoroughly excluded is that of history. Women have been all but entirely wiped off the standard historical record.... This is both a direct consequence of women's subordinate status in a maledominated world and an effective means of furthering it. Women were not deemed important, so women were not included in the history books, and the fact that women do not appear in history books perpetuates the notion that women are not important -- never were and never will be.

$[\ldots]$ the exclusion of women from history has a disastrous effect on our sense of worth. When a boy reads history, he is instantly validated; he finds strong images of male warriors, conquerors, explorers, inventors - images with which he can bond, and which enhance his self-esteem. When a girl reads history, she is instantly invalidated; she too, finds images of male warriors, conquerors, explorers, inventors. But these are not images with which the girl can readily identify. She looks, in longing, for strong female images, but does not find them.... Conventional history gives the girl nothing, literally nothing. It is no wonder so many women feel "full of blanks" when the history of our sex is represented by blank spaces. ${ }^{19}$

For sure, Women and Self-Esteem could be categorized as a self-help book, and similar to Dempsey's article it was published twenty-five years ago. But unfortunately, despite the hard work of historians of women over the ensuing decades, if my students have any credibility, their response to what Sanford and Donovan say about women and history suggest that their assessment still rings true for many.

Strides have been made since the 1990s when Dempsey, Sanford and Donovan were insisting that history was necessary for identity-building. And yet, students are hungry for more knowledge on the often still veiled and mysterious place that women hold in the Christian tradition. Students are also looking for a balanced treatment that will include Indigenous voices. What is missing for both women and Indigenous Peoples is the commitment to being intentional about portraying them as agents and actors in history. For both groups this historical portrayal is essential to identity-building. And there is more; this brings me to my third and final point.

17. King discusses the contemporary image of the Indian, Inconvenient Indian, $21 \mathrm{ff}$.

18. Dempsey, "Role of Native Cultures," 39.

19. Linda Tschirhart Sanford and Mary Ellen Donovan, Women and Self-Esteem: Understanding and Improving the Way We Think and Feel About Ourselves (New York: Penguin, 1985), 184. 


\section{These Histories are Integral to Understanding Our History as a Canadian People}

In April 1982, Gerda Lerner - an American Jewish historian who is credited as the founder of Women's Studies - spoke about the necessity of incorporating women into our understandings of history to the Organization of American Historians in Philadelphia. As Lerner would later point out in Why History Matters, although "women have been denied the power to define, to share in creating the mental constructs that explain and order the world," history shows that women have always, as have men, been agents and actors in history." ${ }^{20}$ Although she was addressing the need for women's history, Lerner's words ring equally true when considering Indigenous history. We do not have to look far to recognize this truth, for historians have provided us with excellent revisionist work on both Indigenous and women's history.

At the Congress of Humanities and Social Sciences 2016 meetings, the Canadian Society of Church History, the Canadian Catholic Historical Association, and the Canadian Historical Association collaborated to bring in Professor J. R. Miller to share his expertise on Residential Schools and Reconciliation. ${ }^{21}$ Miller's work - and the revisionist work of others, including John Milloy, Sarah Carter, Bruce Trigger, and Allen Greer - features prominently in the Truth and Reconciliation Committee's report and the earlier Royal Commission Report on Aboriginal Peoples. ${ }^{22}$ Historians are urged to "integrate Indigenous knowledge and teaching methods into [our] classrooms.",23

Canadian historians of women - Alison Prentice, Wendy Mitchinson, Nancy Christie, Marguerite Van Die, Marilyn Whiteley, and others - have made historiographical shifts that demonstrate beyond a doubt that it is essential to include women, if we are to fully understand our history. ${ }^{24}$ And yet, despite this energetic research, how much influence have these historiographic shifts in Aboriginal and women's history had on how history is done ${ }^{25}$ How much influence have they had on how Canadian church history is being approached through research and in the classroom? Student concerns suggest not nearly enough. Historians of Christianity need to be intentional about including these histories. This is necessary because the histories

20. Lerner, Why History Matters, 207.

21. J.R. Miller, Shingwauk's Vision: A History of Native Residential Schools (Toronto: University of Toronto Press, 1997).

22. See: Truth and Reconciliation Commission of Canada, Final Report of the Truth and Reconciliation Commission of Canada: Vol. 1 Summary: Honouring the Truth, Reconciling for the Future (Toronto: James Lorimer \& Company, 2015). See also: John S. Milloy, A National Crime: The Canadian Government and the Residential School System, 1879-1986 (Winnipeg, MB: University of Manitoba, 1999); Sarah Carter and Patricia McCormack, Recollecting: Lives of Aboriginal Women of the Canadian Northwest and Borderlands (Edmonton: Athabasca University Press, 2011); Bruce Trigger, The Huron: Farmers of Fort Worth (Fort Worth: Holt, Rinehart and Winston, 1990); Trigger, The Children of Aataentsic: A History of the Huron People to 1660 (Montreal, QC: McGill-Queen's University Press, 1976); Allan Greer, The Jesuit Relations: Natives and Missionaries in Seventeenth-Century North America (Boston: Bedford/St. Martin's, 2000); Greer, Mohawk Saint: Catherine Tekakwitha and the Jesuits (New York: Oxford University Press, 2005).

23. Final Report of the Truth and Reconciliation Commission, 331.

24. See, for instance: Alison Prentice and Marjorie R. Theobald, eds., Women Who Taught: Perspectives on the History of Women and Teaching (Toronto: University of Toronto Press, 1991); Jenny Ellison, Deborah McPhail, and Wendy Mitchinson, eds., Obesity in Canada: Critical Perspectives (Toronto: University of Toronto Press, 2016); Elizabeth Gillan Muir and Marilyn Färdig Whiteley, eds., Changing Roles of Women Within the Christian Church in Canada (Toronto: University of Toronto Press, 1995); Whiteley, Canadian Methodist Women, 1766-1925: Marys, Marthas, Mothers in Israel (Waterloo, ON: Wilfrid Laurier University Press, 2005); Muir, Petticoats in the Pulpit: The Story of Early Nineteenth-Century Methodist Women Preachers in Upper Canada (Toronto: United Church Publishing House, 1991); Marguerite Van Die, Religion, Family, and Community in Victorian Canada: The Colbys of Carrollcroft (Montreal, QC: McGill-Queen's University Press, 2005); Nancy Christie, Households of Faith: Family, Gender, and Community in Canada, 1760-1969 (Montreal, QC: McGillQueen's University Press, 2002).

25. Thomas Peace has raised this question for Indigenous history in "Truth and Reconciliation While Teaching Canadian History?" Active History, November 23, 2015, http://activehistory.ca/2015/11/truth-and-reconciliation-while-teachingcanadian-history/. 
of Indigenous Peoples and women are essential to understanding who we are as a Canadian people. They are not just their stories; they are our stories.

With these concerns that have been primary throughout my academic career, I was delighted to see the commemorative bank note that came out last June. Whatever we make of the political intent of representing diversity on this ten-dollar bill marking Canada's 150 years, we would be remiss not to embrace this attempt to highlight the significance of women's history and the history of Indigenous Peoples.

Some of you may be familiar with Palmer Parker's work. In The Courage to Teach, Parker has suggested that "knowing of any sort is relational, animated by a desire to come into deeper community with what we know. Why does a historian study the dead 'past'?" he asks: "To reveal how much of it lives today. ${ }^{26}$ Our commemorative $\$ 10.00$ bill raises the question - just how much do the histories of women and indigenous people live in us today?

Curious about how the lives of James Gladstone and Agnes Macphail expand our knowledge of Canadian history, I decided to explore their stories. What do their contributions suggest about the necessity of including women's and indigenous history in the way we research and teach church history? Is their history our history? Hugh Dempsey's biography of James Gladstone, Gentle Persuader (1986), and Terry Crowley's Agnes MacPhail and the Politics of Equality (1990), are helpful in thinking about these questions.

Hugh Dempsey, whom I have already introduced as the curator of the Glenbow museum, was also James Gladstone's son-in-law. As a young man he fell in love with Gladstone's daughter Pauline, and they enjoyed a long marriage. Is Dempsey's account objective? Not fully. It takes an insider-outsider perspective, telling the difficulties Gladstone faced growing up in southern Alberta, in a Cree-Scots-French family, neither white nor Indian. It is a story of mixed race, mixed culture (Indigenous; Scottish-French), and mixed religious background (Anglican and practitioner of the Sundance). It is a story of suffering as a young child in a residential school, of seeking belonging through joining the Blood Indians; it is a story of difficulties transformed to make the Canada of the mid-nineteenth century a more hospitable place for Indigenous Peoples. As President of what was then known as the Indian Association of Alberta, Gladstone devoted his life to bettering the situation for his people; with his ability to bring different groups together he fought for improved education, increased respect for treaty rights, and encouraged Indigenous people to involve themselves in administrating their own governing structures and land. ${ }^{27}$

Terry Crowley's biography of Agnes Macphail is also "relational." Crowley wrote it in response to his students' desire for more women's history. Crowley adapted his teaching priorities and offered the first Women's Studies course at Guelph University. ${ }^{28} \mathrm{He}$ carved out the time to research and write the life of a woman who distilled the challenges she faced as she defied the conventions of the rural Ontario community where she was born, a woman who turned to unorthodox Christianity - the Church of the Jesus Christ and the Latter Day Saints - to fuel her own deep heart for justice. She would become a champion of rural Canadians. Like Gladstone, Macphail would transform her particular struggles to improve the lives of her people. For Macphail, the desire to escape the conventions of rural Ontario became a lifetime of working for justice for rural Canadians from east to west. ${ }^{29}$ Influenced by former Methodist clergyman James S.

26. Parker Palmer, The Courage to Teach (San Francisco, CA: Jossey-Bass, 1998), 54.

27. Dempsey, Gentle Persuader, 123-24; James Dempsey, "James Gladstone," The Canadian Encyclopedia (Historica Canada). Article published January 30, 2008; Last modified March 4, 2015. http://www.thecanadianencyclopedia.ca/en/ article/james-gladstone/; Patricia Williams, "John Diefenbaker," The Canadian Encyclopedia (Historica Canada). Article published February 21, 2008; Last modified March 4, 2015. http://www.thecanadianencyclopedia.ca/en/article/johndiefenbaker/.

28. Terry Crowley, Agnes Macphail and the Politics of Equality (Toronto: James Lorimer \& Company, 1990), vi. 29. Crowley, Agnes Macphail, 88. 
Woodsworth's Social Gospel, the Independent Labour Party which Woodsworth represented as Winnipeg Member of Parliament and Alberta's Progressives, Macphail adopted a pacifist stance. Deeply involved with the Women's International League for Peace and Freedom, well ahead of her time, she also became known for her commitment to inter-racial relations and rights, and prison reform. ${ }^{30}$

James Gladstone and Agnes Macphail - two leaders whose images accompany those of MacDonald and Cartier on the commemorative bill put out to mark Canada's sesquicentennial - were non-conformists; neither fit in neat categories. Although Gladstone supported the Sun Dance, he remained a strong supporter of the Anglican Church throughout his lifetime. Despite difficult conditions in residential schools, he sent his children to his own Alma Mater, St. Paul's. ${ }^{31}$ On her part, Macphail took "biblical injunctions against undo concern with material wealth seriously," and was known to be "charitable to a fault." ${ }^{32}$ Late in life, she would became active in the local United Church, teaching Sunday School, and recalling how many a time as she stood in the House of Commons, she "prayed for direction on how to vote." As much as Macphail's belief in God under girded her strong sense of justice and her call to work for the little person, ${ }^{33}$ Gladstone also was known to make leadership decisions on what he knew of the Bible. ${ }^{34}$ At her premature death on February 13, 1954, at the age of sixty-three, Prime Minister Louis St. Laurent lamented that he had hoped to appoint Agnes Macphail to the Senate. ${ }^{35}$ Four years later, James Gladstone would become the first Indigenous person to become Senator. Gladstone and Macphail are much more than convenient symbols on a commemorative ten-dollar bill. Their history is much more than women's history and Indigenous history. Their images hold the potential to alter the way women and Indigenous people see themselves. As a Canadian people, they represent our history.

As anyone who has worked at incorporating Indigenous and women's history into research and teaching knows, it is neither obvious, nor easy. It means making decisions. What do we leave out, so we can add in? Who makes the decision about what is important, and what is not? How do we move beyond awkwardly adding to our already full agendas? How do we integrate histories of women and Indigenous Peoples, and other non-mainstream histories, into the big picture? Until we have textbooks that provide balanced history, such integration may be messy and awkward. A fair question and guideline can be taken from Parker Palmer. How much does our Indigenous past, to quote Palmer Parker, live in us today? Highlighting treaty making, and of course the history of the church's complicity in residential schools is important. But how has the resistance of Plains Cree and Blackfoot leaders also influenced the history of Christianity? Are there precursors to the Social Gospel as it played out in the history of indigenous resistance in the Canadian West? Wallace Stegner, Ralston Saul, D'Arcy Jenish have provided memoirs, philosophical ideas, and histories that are suggestive in thinking about the indigenous roots of the Christian Canada that has evolved post-1867. ${ }^{36}$

As we search for a Christian Canada, do we explore gender roles, how much women's contributions, to quote Palmer Parker, live in us today? I have found the work of Marguerite Van Die, Marilyn Whiteley,

30. Crowley, Agnes Macphail, 65-66, 96.

31. Dempsey, "James Gladstone," 68-72.

32. Crowley, Agnes Macphail, 60.

33. Crowley, Agnes Macphail, 201.

34. Dempsey, "James Gladstone," 66.

35. Crowley, Agnes Macphail, 204.

36. See D'Arcy Jenish, Indian Fall: The Last Great Days of the Plains Cree and the Blackfoot Confederacy (Toronto, ON; Penguin Books, 1999) for a compelling and accessible telling of this story. Wallace Stegner's Wolf Willow: A History, a Story, and a Memory of the Last Plains Frontier (New York: Penguin Books, 1990) is suggestive regarding the unarticulated influence of indigenous peoples. See also John Ralston Saul, A Fair Country: Telling Truths About Canada (Toronto: Penguin Books, 2008). 
Elizabeth Muir cited earlier for example, to be thought provoking and helpful in exploring the female face of Confederation and post-Confederation Canada. Why is the history of women and Indigenous Peoples necessary? It is necessary in building a healthy past that includes those who were first on this land, and the women who have always been there. It is necessary for the healing of individuals, and of our nation. Underneath it all, the bottom line, is that the history of women and Indigenous Peoples is necessary, because it is our history.

Ending with Parker Palmer, the past does live in us today. The hope of the early Christians has not yet arrived. Many still await the Parousia or Second Coming. As we mark 500 years since the Luther Reformation and 150 years since Canadian Confederation, we do have the opportunity to take a fresh look at women's history, to take a fresh look at Indigenous history. It is our task to continue to explore just "how much of it lives in us today.",37

37. Palmer, Courage to Teach, 54. 


\section{Bibliography}

Blatchford, Christie. Helpless: Caledonia's Nightmare of Fear and Anarchy, and How the Law Failed All of Us. Toronto: Doubleday, 2010.

Carter, Sarah, and Patricia McCormack. Recollecting: Lives of Aboriginal Women of the Canadian Northwest and Borderlands. Edmonton, AB: Athabasca University Press, 2011.

Christie, Nancy. Households of Faith: Family, Gender, and Community in Canada, 1760-1969. Montreal, QC: McGill-Queen's University Press, 2002.

Crowley, Terry. Agnes Macphail and the Politics of Equality. Toronto, ON: James Lorimer \& Company Publishers, 1990.

Dempsey, Hugh A. The Gentle Persuader: A Biography of James Gladstone Indian Senator. Saskatoon, SK: Western Producer Prairie Books, 1986.

—. "Role of Native Cultures in Western History: An Alberta Focus." In The Cultural Maze: Complex Questions on Native Destiny in Western Canada, edited by John W. Friesen, 39-52. Calgary, AB: Detselig Enterprises, 1991.

Ellison, Jenny, Deborah McPhail, and Wendy Mitchinson, eds. Obesity in Canada: Critical Perspectives. Toronto, University of Toronto Press, 2016.

Greer, Allan. The Jesuit Relations: Natives and Missionaries in Seventeenth-Century North America. Boston: Bedford/St. Martin's, 2000.

—. Mohawk Saint: Catherine Tekakwitha and the Jesuits. New York: Oxford University Press, 2005.

Holmes, Urban T. III. A History of Christian Spirituality: An Analytical Introduction. New York: Seabury Press, 1981.

Jenish, D'Arcy. Indian Fall: The Last Great Days of the Plains Cree and the Blackfoot Confederacy. Toronto: Penguin Books, 1999.

King, Thomas. The Inconvenient Indian: A curious Account of Native People in North America. Toronto: Doubleday Canada, 2002.

Lerner, Gerda. Why History Matters: Life and Thought. New York: Oxford University Press, 1997.

Levine, Allan. "Slow Road to Tolerance.” Canada’s History (April-May 2016): 41-47.

Marr, Lucille. "'Breaking Down Barriers': Mennonite Central Committee Ontario and Ontario Native Communities.” Journal of Mennonite Studies 18 (2000): 78-91.

_- "Spirituality and a Heart for Justice: Mennonite Central Committee and the Ontario Aboriginal Community." Brethren in Christ History and Life 26, no.2 (2003): 45-61.

. "Writing a Woman's Life: Lucille Brechbill Lady, 1910-1968." Brethren in Christ History and Life 33, no. 1 (2010): 3-50. 
."Breaking the Silence on Suicide and Mental Illness: The Brethren in Christ, 1968-1989." Journal of Mennonite Studies 29 (2011): 121-32.

. "“Paying the Price of War': Women on the Home Front." In Canadian Churches and the First World War, edited by Gordon L. Heath, 263-283. Eugene OR: Pickwick Publications, 2014.

—. "Jane Drummond Redpath." In Still Voices-Still Heard, edited by J.S.S. Armour, Judith Kashul, William Klempa, Lucille Marr, and Dan Schute, 44-62. Eugene, OR: Wipf \& Stock, 2015.

—. "Conflict, Confession and Conversion: H. Frances Davidson's Call to Brethren in Christ Mission.” Brethren in Christ History \& Life 40, no. 3 (December 2017): 335-52.

—. "Women and Christianity." In Women and the Future of Religion, edited by Arvind Sharma. New York: Suny Press, forthcoming.

Miller, J.R. Shingwauk's Vision: A History of Native Residential Schools. Toronto: University of Toronto Press, 1997.

Milloy, John S. A National Crime: The Canadian Government and the Residential School System, 18791986. Winnipeg, MB: University of Manitoba, 1999.

Moir, John S. "The Search for a Christian Canada." In Christianity in Canada: Historical Essays, edited by Paul Laverdure, 9-24. Yorktown, SK: Redeemer's Voice Press, 2002.

Muir, Elizabeth Gillan, Petticoats in the Pulpit: The Story of Early Nineteenth-Century Methodist Women Preachers in Upper Canada. Toronto: United Church Publishing House, 1991.

— Canada. Toronto: University of Toronto Press, 1995.

Palmer, Parker. The Courage to Teach. San Francisco, CA: Jossey-Bass, 1998.

Prentice, Alison, and Marjorie R. Theobald, eds. Women Who Taught: Perspectives on the History of Women and Teaching Toronto: University of Toronto Press, 1991.

Sanford, Linda T. and Mary Ellen Donovan. Women and Self-Esteem: Understanding and Improving the Way We Think and Feel about Ourselves. New York: Penguin, 1985.

Saul, John Ralston. A Fair Country: Telling Truths About Canada. Toronto: Penguin Books, 2008.

Sharma, Arvind, ed. Women and the Future of Religion. New York: Suny Press, forthcoming.

Stegner, Wallace. Wolf Willow: A History, a Story, and a Memory of the Last Plains Frontier. Toronto: Penguin Books, 1990.

Trigger, Bruce. The Children of Aataentsic: A History of the Huron People to 1660. Montreal, QC: McGill-Queen's University Press, 1976.

- The Huron: Farmers of Fort Worth. Fort Worth, TX: Holt, Rinehart and Winston, 1990. 
Truth and Reconciliation Commission of Canada. Final Report of the Truth and Reconciliation Commission of Canada: Vol. 1 Summary: Honouring the Truth, Reconciling for the Future. Toronto: James Lorimer \& Company, 2015.

Van Die, Marguerite. Religion, Family, and Community in Victorian Canada: The Colbys of Carrollcroft. Montreal, QC: McGill-Queen's University Press, 2005.

Whiteley, Marilyn Färdig. Canadian Methodist Women, 1766-1925: Marys, Marthas, Mothers in Israel Waterloo, ON: Wilfrid Laurier University Press, 2005.

Wright, Nicholas Thomas. Surprised by Hope: Rethinking Heaven, the Resurrection, and the Mission of the Church. New York: Harper Collins Publishers, 2008. 